\title{
Kanserin Önlenmesi ve Tedavisinde Polifenollerin Rolü
}

\section{The Role of Polyphenols on Cancer Prevention and Treatment}

\author{
Şenay Burçin Alkan ${ }^{1 *}$, Neslişah Rakıcıoğlu ${ }^{2}$ \\ ${ }^{1}$ Necmettin Erbakan Üniversitesi, Sağlık Bilimleri Fakültesi Beslenme ve Diyetetik Bölümü, Konya, Türkiye. \\ ${ }^{2}$ Hacettepe Üniversitesi, Sağlık Bilimleri Fakültesi, Beslenme ve Diyetetik Bölümü, Ankara, Türkiye \\ e-mail: sbalkan@erbakan.edu.tr, neslisah@hacettepe.edu.tr. \\ ORCID: 0000-0001-5465-1210 \\ ORCID: 0000-0001-8763-7407 \\ *Sorumlu yazar/ Corresponding Author: Şenay Burçin Alkan \\ Gönderim Tarihi / Received: 22.10.2020 \\ Kabul Tarihi / Accepted: 03.11.2021 \\ DOI: $10.34087 /$ cbusbed. 814154
}

Kanser, dünya genelinde ölüm oranının yüksek olduğu hastalıklar arasında yer almaktadır. Kanser vakalarının sadece \%5-10'u genetik faktörler, \%90-95'i ise çevresel, fiziksel faktörler ve hormonlar nedeniyle gelişmektedir. Beslenme, çevresel faktörler arasında yer almakta ve kanser metabolizmasını farklı yolaklarla etkileyebilmektedir. Son yıllarda makro ve mikro besin öğelerinin yanı sıra polifenollerin kanseri önlemede ve tedavisindeki etkisi üzerinde durulmaktadır. Polifenoller bitkilerin çiçek, yaprak, meyve, sap ve kök gibi bölümlerinde bulunan sekonder metabolitlerdir ve flavonoidler, fenolik asitler, stilbenler ve lignanlar olarak dört sınıfta incelenmektedir Yetişkin bireylerin diyetle polifenol alımının değerlendirildiği araştırmalarda toplumlar arasında farklılıklar olduğu görülmektedir. Bununla birlikte genel olarak değerlendirildiğinde kahve ve çayın günlük polifenol alımına önemli katkısının olduğu dikkat çekmektedir. Epidemiyolojik çalışmalar ve meta analizlerde, diyetle yüksek polifenol alımının kanser riskini azaltabileceği belirtilmektedir. Klinik çalışmalarda ise yeşil çay polifenolleri, izoflavonoid, kurkumin ve resveratrol gibi bileşiklerin kanserin önlemesi ve tedavisinde etkili olabileceği bildirilmiştir. Hücre kültürü ve deney hayvanları çalışmalarında polifenollerin farklı kanser hücrelerinde anjiogenez, migrasyon, proliferasyon, metastaz, tümör gelişimini inhibe ettiği, apoptozisi ise indüklediği gösterilmiştir. Ancak insanlar üzerinde yapılan klinik çalışmaların sayısı sınırlıdır. Bu nedenle kanserin önlenmesi ve tedavisinde polifenollerin kullanılması ile ilgili görüş birliğinin sağlanmasında bilimsel kanıtlar yetersizdir. Farklı kanser türleri ve evrelerinde kullanılacak olan polifenolün türü, miktarı, kullanım süresi ve olası yan etkilerinin belirlenmesi için klinik yeni çalışmalara gereksinim vardır.

Anahtar kelimeler: Beslenme, Kanser, Polifenoller.

Abstract
Cancer is a disease with a high worldwide mortality rate. Only 5-10\% of cancer cases develop due to genetic factors
and 90-95\% develop due to environmental and physical factors and hormones, including nutrition. Nutrition can affect
cancer metabolism via different pathways. In addition to macro- and micronutrients, the impact of polyphenols on
cancer prevention and treatment has been emphasized. Polyphenols are secondary metabolites found in parts of plants
such as flowers, leaves, fruits, stems and roots, and classified into four categories based on their structure flavonoids,
phenolic acids, lignans and stilbenes. There are differences between societies in terms of dietary polyphenol intake.
However, when evaluated in general, it is noteworthy coffee and tea have an important contribution to the daily intake
of polyphenols. Epidemiological studies and meta-analyses indicate dietary high polyphenol intake can reduce the
risk of cancer. It has been reported several compounds, such as green tea polyphenols, isoflavonoid, curcumin, and
resveratrol, could be effective in the prevention and treatment of cancer. In cell culture and experimental animal
studies, polyphenols have been shown to inhibit angiogenesis, migration, proliferation, metastasis, and tumor


development in cancer cells and induce apoptosis. However, the number of clinical studies of polyphenols in humans is limited. Therefore, the scientific evidence is insufficient to provide a consensus regarding the use of polyphenols in prevention and treatment of cancer. Clinical studies are needed to determine the type, amount, duration and possible side effect of polyphenol to be used in different cancer types and stages.

Keywords: Cancer, Nutrition, Polyphenols.

\section{Giriş}

Kanser, dünya genelinde ölüme neden olan hastalıklar arasında ikinci sırada yer almaktadır ve 2018 yılında yaklaşı 9,6 milyon kişinin kanser nedeniyle hayatını kaybettiği tahmin edilmektedir. Erkek bireylerde en sık görülen kanser türleri akciğer, prostat, kolorektal, mide ve karaciğer kanseri iken kadın bireylerde meme, kolorektal, akciğer, serviks ve troid kanserleri daha sık görülmektedir (1).

Tüm kanser vakalarının sadece $\% 5-10$ 'u genetik faktörler \%90-95' $\mathrm{i}$ ise çevresel, fiziksel faktörler ve hormonlar nedeniyle gelişmektedir. Çevresel faktörler arasında yaşam biçimi, diyet, obezite, sigara ve alkol kullanımı, stres, yetersiz fiziksel aktivite; fiziksel faktörler arasında ise kirleticiler, viral/bakteriyel/parazitik enfeksiyonlar, iyonize ve iyonize olmayan radyasyon yer almaktadır. Bazı hormonların da (insülin benzeri büyüme faktörü vb. gibi) karsinogeneze neden olabileceği belirtilmektedir (2).

Beslenme kansere neden olan faktörlerin yaklaşık \%35'ini oluşturmaktadır ve kanserojen metabolizması, hücre ve konak savunması, hücre farklılaşması, tümör büyümesi gibi aşamalarda kanser metabolizmasını etkileyebilmektedir (3). Diyet ve kanser arasındaki ilişki değerlendirilirken, beslenme biçimi ve alışkanlıkları da ele alınmaktadır. Örneğin süt, meyve ve sebzelerin tüketilmesi; posa, selenyum, kalsiyum, karotenoid, C, E, B6 vitaminleri, folat ve flavonoid içermesi nedeniyle düzenli ve yeterli miktarda tüketilmesi kansere karşı koruyucu olurken, alkol tüketimi ve doymuş yağ içeriği yüksek olan kırmızı et ve işlenmiş et ürünlerinin fazla tüketilmesi kanser riskini artırmaktadır. Bununla birlikte besin hazırlama ve pişirme sırasında oluşan heterosiklik aminler, polisiklik hidrokarbonların alımı, fazla tuz kullanımı, arsenikli su ve mikotoksin içeren besinlerin tüketimi gibi faktörler de kansere neden olabilmektedir $(3,4)$. Kanser hücrelerinin moleküler mekanizmasıyla ilgili önemli bulgular elde edilmesine rağmen kanserin erken teşhis ve tedavisiyle ilgili sorunlarla karşılaşılmaktadır.

Kanserin medikal tedavisinde kullanılan cerrahi, radyoterapi (fotodinamik terapiyi içerir), kemoterapi (hormonal ve moleküler tedaviyi içerir) ve biyolojik tedaviler (immünoterapi ve gen tedavisini içerir) her hastada olumlu sonuç vermemektedir. Bu nedenle araştırmacılar kanserin önlenmesi, erken teşhisi ve tedavisi için yeni yöntemler üzerinde çalışmaktadır (5). Epidemiyolojik çalışmalardan elde edilen veriler, polifenollerin kansere karşı korucu etkisinin olduğunu göstermektedir. Son y1llarda polifenollerin kanseri önleme ve tedavisindeki rolünün anlaşılabilmesi için in vitro, deney hayvanları ve klinik çalışmalar dikkat çekmektedir.
Bu derleme yazıda erkek ve kadın bireylerde sık görülen kanser türleri olan akciğer, prostat, kolorektal, mide, karaciğer ve meme kanseri ile polifenoller arasındaki ilişki incelenecektir.

\section{Polifenoller}

Polifenoller bitkilerin çiçek, yaprak, meyve, sap ve kök gibi bölümlerinde bulunan sekonder metabolitlerdir (6). Yapılarında birden fazla fenol halkası bulunan fenolik bileşikler, karbon iskeletlerinin yapısı ve heterosiklik halkaların hidroksilasyon, oksidasyon, glikolizasyon ve asilasyon durumuna göre flavonoidler, fenolik asitler, stilbenler ve lignanlar olarak dört sinıfta incelenmektedir (7).

\subsection{Yetişkin Bireylerin Günlük Polifenol Alımı}

Yetişkin bireylerin polifenol alımları ile ilgili farklı toplumlarda yapılan çalışmalar bulunmaktadır. Ülkede yetiştirilen meyve, sebze ve diğer bitkiler ile beslenme kültürü polifenol alımını etkilemektedir. Tablo 1'de son yıllarda yapılan ve günlük polifenol alımının değerlendirildiği çalışmalara yer verilmiştir. Toplam polifenol alımında ülkeler arasında farklılıklar olduğu görülmektedir. Bununla birlikte bulgular genel olarak değerlendirildiğinde kahve ve çayın günlük polifenol alımına önemli katkısının olduğu dikkat çekmektedir (811).

\section{Polifenoller ve Kanser}

Polifenol içeriği yüksek olan meyve, sebze gibi bitkisel kaynaklı besinlerin tüketiminin kanser insidansını azalttığı bildirilmiştir (12). Hücre kültürü ve deney hayvanlarıyla yapılan çalışmalar polifenollerin antikarsinojenik özelliklerinin daha iyi anlaşılmasını sağlamıştır. Polifenollerin; oksidasyonu, inflamasyonu ve metastazı önlediği, apoptozisi indüklediği, immün sistem fonksiyonlarını iyileştirdiği ve karsinogenezin ilerlemesiyle ilgili sinyal iletim yollarını etkilediği gösterilmiştir (13).

\subsection{Epidemiyolojik ve Vaka-Kontrol Çalışmaları}

Polifenol alımı ve kanser riski arasındaki ilişkiyi inceleyen çok sayıda prospektif, retrospektif kohort çalışma, vaka-kontrol çalışmaları ve meta analiz bulunmaktadır (14-49).

\subsubsection{Akciğer Kanseri}

Kanada'da diyetle polifenol alımının akciğer kanser riski ile ilişkisinin incelendiği bir vaka kontrol çalışmasında yaş, cinsiyet, sigara kullanımı, karsinojene maruziyet, beden kütle indeksi, enerji alımı gibi faktörlere göre düzeltme yapıldıktan sonra toplam flavonoid alımıla akciğer kanser riski arasında anlamlı ilişki 
Tablo 1. Yetişkin bireylerin günlük polifenol alımı (8-11)

\begin{tabular}{|c|c|c|}
\hline Ülke\&Bireyler & Yöntem & Bulgular \\
\hline $\begin{array}{l}\text { Polonya, } 45-69 \text { yaş arası } 10.477 \\
\text { birey } \\
\text { HAPIEE çalışması } \\
\text { (Health, Alcohol and Psychosocial } \\
\text { factors In Eastern Europe) }\end{array}$ & $\begin{array}{c}\text { Son } 3 \text { aylık } \\
\text { besin tüketim sıklığ ve } \\
\text { Phenol -Explorer } \\
\text { veritabanı }\end{array}$ & $\begin{array}{c}\text { Toplam polifenol alımı } \rightarrow 1756,5 \pm 695,8 \mathrm{mg} / \text { gün } \\
\text { flavonoid alımı } \rightarrow 897 \mathrm{mg} / \text { gün } \\
\text { fenolik asit alımı } \rightarrow 800 \mathrm{mg} / \text { gün }\end{array}$ \\
\hline Brezilya, 20 yaş üstü 1.103 birey & $\begin{array}{l}24 \text { saatlik geriye dönük } \\
\text { besin tüketim kaydı ve } \\
\text { Phenol -Explorer } \\
\text { veritabanı }\end{array}$ & $\begin{array}{c}\text { Toplam polifenol alımı } \rightarrow 377,5 \pm 15,3 \mathrm{mg} / \text { gün } \\
\text { fenolik asit alımı } \rightarrow 284,8 \pm 5,9 \mathrm{mg} / \mathrm{gün} \\
\text { flavonoid alımı } \rightarrow 54,9 \pm 3,5 \mathrm{mg} / \mathrm{gün} \\
\text { Polifenol alımına en çok katkısı besinler: kahve, turunçgil ve tropikal } \\
\text { meyveler }\end{array}$ \\
\hline $\begin{array}{l}\text { Avrupa Kanser ve Beslenme } \\
\text { Araştırması (EPIC, The European } \\
\text { Prospective Investigation into } \\
\text { Cancer and Nutrition) } \\
36.037 \text { yetişkin birey }\end{array}$ & $\begin{array}{l}24 \text { saatlik geriye dönük } \\
\text { besin tüketim kaydı ve } \\
\text { Phenol -Explorer } \\
\text { veritabanı }\end{array}$ & $\begin{array}{c}\text { Toplam polifenol alımı } \\
\text { en yüksek olan ülke Danimarka (erkeklerde } 1786 \text { mg/gün, kadınlarda } \\
1626 \text { mg/gün), } \\
\text { en düşük olan ülke Yunanistan (erkeklerde } 744 \text { mg/gün, kadınlarda } 584 \\
\text { mg/gün) } \\
\text { Polifenol alımına en çok katkısı olan besinler: kahve, çay ve meyveler }\end{array}$ \\
\hline $\begin{array}{l}\text { İtalya, } 1.937 \text { yetişkin birey } \\
\text { MEAL çalışması } \\
\text { (Mediterranean healthy Eating, } \\
\text { Aging and Lifestyle) }\end{array}$ & $\begin{array}{l}\text { Besin tüketim sıklığı ve } \\
\text { Phenol -Explorer } \\
\text { veritabanı }\end{array}$ & $\begin{array}{c}\text { Toplam polifenol alımı } \rightarrow 663,7 \mathrm{mg} / \mathrm{gün} \\
\text { fenolik asit alımı } \rightarrow 362,7 \mathrm{mg} \mathrm{mg} / \mathrm{gün} \\
\text { flavonoid alımı } \rightarrow 258,7 \mathrm{mg} / \mathrm{gün} \\
\text { Polifenol alımına en çok katkısı olan ilk üç besin:Sert kabuklu meyveler, } \\
\text { çay ve kahve }\end{array}$ \\
\hline
\end{tabular}

bulunmamıștır. Flavon ve flavanon alımı yüksek olan bireylerde ise akciğer kanser riskinin anlamlı olarak düşük olduğu gösterilmiştir. Aynı çalışmada flavon ve flavanon alımına en çok katkı sağlayan besinlerin turunçgiller, marul, kavun, elma/armut olduğu belirlenmiştir (14).

Kırk iki araştırmanın yer aldığ 1 bir meta analizde siyah çay tüketiminin akciğer kanser riskini azaltmada anlamlı bir etkisi bulunmazken, günde 7,5 gram yeşil çay tüketiminin epigallo kateşin gallat içeriğinden dolayı, akciğer kanser riskini azaltabileceği gösterilmiştir. Çay tüketiminin sigara içmeyen bireylerde koruyucu etkisinin yanı sıra yapılan ileri analizlerde günde en az 2,5 g yeşil çay tüketen ve sigara içen bireylerde riskin azaldığı vurgulanmıştır (15).

\subsubsection{Prostat Kanseri}

İtalya'da yapılan bir vaka-kontrol çalışmasında fenolik asit grubunda yer alan kafeik asit ve ferulik asidin, prostat kanserine karşı koruyucu olduğu gösterilmiştir (16). Sert kabuklu meyve ve kahve tüketiminin fenolik asit alımına en çok katkı sağlayan besinler olduğu bulunmuştur. Ferulik asidin prostat kanser hücrelerinde proliferasyonu önlediği ve onkogen ekspresyonunu azalttığı, kafeik asidin ise nükleer faktör kapa betayı inhibe ettiği olası mekanizmalar arasında yer almaktadır (16). Amerika'da yapılan bir kohort çalışmada ise toplam flavonoid alımı ve alt gruplarının, prostat kanserine karşı koruyucu etki göstermediği belirlenmiştir (17). Bir meta analizde, toplam flavonoid alımı ile prostat kanseri arasında anlamlı bir ilişki bulunmazken (18), diğer bir meta analizde ise günde en az 7 fincan yeşil çay tüketiminin prostat kanser riskini \%19 azalttığı gösterilmiştir. Yeşil çayda bulunan epigallo kateşin galatın anjiogenezi, metastazı, hücre büyümesini inhibe ederek ve apoptozisi indükleyerek, prostat kanserine karşı koruyucu etki gösterebileceği vurgulanmaktadır (19).

\subsubsection{Kolorektal kanser}

Çin'de yapılan vaka kontrol çalışmasında toplam flavonoid alımının kolorektal kanserini önlemede etkili olmadığı, ancak alt grup olan flavanon ve flavon alımının riski azalttığı gösterilmiştir (20). Günlük flavanon alıma en çok katkı sağlayan besinlerin turunçgiller olduğu; flavon kaynaklarının ise kereviz, biber ve lahana olduğu belirtilmiştir. Özellikle flavanonların kolon kanser hücrelerinde apoptozisi indüklediği ve antiproliferatif etki gösterdiği bildirilmektedir. Bununla birlikte meyve ve sebzelerle alınan posa ve karoten gibi bazı vitaminlerin de kansere karşı koruyucu etki gösterebileceği vurgulanmaktadır (20). Amerika'da 26 yıl süren bir kohort çalışmada ise flavonoid alt grupları ile kolorektal kanser riski arasında anlamlı bir ilişki bulunmamıştır. Polifenoller ile kolorektal kanser riski arasındaki ilişki incelenirken, barsak mikrobiyotasının da değerlendirilmesi gerektiği vurgulanmaktadır (21). İki meta analizde ise toplam flavonoidlerin değil, alt gruplarının kolorektal kanser riskini önlemede daha etkili olduğu vurgulanmaktadır $(22,23)$. Çay polifenolleriyle ilgili çalışmaları kapsayan bir meta analizde de çay tüketimi yüksek olan bireylerde risk anlamlı olarak daha düşük bulunmuştur. Özellikle epigallo kateşin galat içeriği yüksek olan yeşil çayın koruyucu etkisi vurgulanmaktadir (24).

\subsubsection{Mide Kanseri}

Avrupa Kanser ve Beslenme Araştırması'nda (EPIC, The European Prospective Investigation into Cancer and Nutrition) 477.312 birey 11 yıl boyunca takip edilmiş ve 
683 mide kanseri vakası saptanmıştır. Toplam flavonoid alımı yüksek olan kadın bireylerde (>580,6 mg/gün) mide kanseri gelişme riskinin daha düşük olduğu bulunmuştur. Erkek bireylerde ise anlamlı bir ilişki bulunmamıştır. Kadınlarda özellikle flavonoidlerin cinsiyet hormonlarıyla etkileşime girerek koruyucu etki gösterdiği düşünülmektedir (25). Kore'de yapılan vakakontrol çalışmasında, toplam flavonoid alımına en çok katkı sağlayan besinlerin yeşil çay, tofu ve siyah soya fasulyesi olduğu tespit edilmiştir. Yüksek flavonoid alımı kadın bireylerde mide kanserine karşı koruyucu etki gösterirken erkek bireylerde anlamlı bir ilişki bulunmamıştır (26). Sekiz vaka-kontrol ve dört prospektif kohort çalışmanın yer aldığı bir meta-analize yüksek flavonol alımının mide kanserine karşı koruyucu olduğu gösterilmiştir. Diyetteki başlıca flavonol olan kuarsetinin tümör hücrelerinin yaşam süresini kısalttığ1, apoptozisi indüklediği ve bazı sinyal yollarıyla reaktif oksijen türlerinin üretimini azalttığı bildirilmiştir (27). Başka bir meta-analizde ise yüksek izoflavon alımının mide kanser riskini anlamlı olarak azalttığı gösterilmiştir (22). İzoflavonoidlerin antioksidan etki göstererek ve mide kanser hücrelerinde büyüme faktörü reseptörü ile ilgili olan trozin kinaz aktivitesini inhibe ederek, mide kanserine karşı olası koruyucu etki gösterdiği düşünülmektedir (28).

\subsubsection{Karaciğer Kanseri}

Polifenol alımı ve karaciğer kanser riskini inceleyen epidemiyolojik ve vaka-kontrol çalışmalarının sayısı sınırlıdır. Bir vaka-kontrol çalışmasında hepatit $\mathrm{C}$ virüsü olan ve olmayan bireylerde flavon alımı ile karaciğer kanser riskinin azaltılabileceği ve flavon alımının ıspanak ve biber tüketimi ile sağlandığ belirtilmiştir (29).

Avrupa Kanser ve Beslenme Araştırması'nda 477.206 birey 11 yıl boyunca izlenmiştir. Toplam flavonoid alımı ile karaciğer kanser riski arasında anlamlı bir ilişki bulunmazken, yüksek flavanol alımının karaciğer kanser riskini azaltabileceği bulunmuştur. Flavanol alımına en çok katkı sağlayan besinlerin çay $(\% 44,1)$, meyveler $(\% 20,1)$, şarap $(\% 8,8)$ ve çikolata ürünleri $(\% 3,8)$ olduğu belirlenmiştir (30). Japonya'da izoflavon alımı ve hepatoselüler kanser riskinin araştırıldığı prospektif kohort çalışmada 19.998 birey ortalama 11,8 yıl izlenmiştir. Erkek bireylerde anlamlı bir ilişki bulunmazken, hepatit virüs taşıyan kadın bireylerde izoflavon alımı ile kanser riskinin artabileceği gösterilmiştir. $\mathrm{Bu}$ durumun östrojen reseptör ve izoflavonların etkileşimi sonucu ortaya çıkabileceği düşünülmektedir. Kadın bireylerde östrojenin karaciğer kanserine karşı koruyucu etkisinin olduğu varsayılmaktadır. İzoflavonların östrojen reseptörüne bağlanması östrojenin koruyucu etkisini olumsuz etkilemektedir (31).

\subsubsection{Meme Kanseri}

Polifenollerin meme kanserinden koruyucu etkisinin incelendiği çalışmalarda daha çok izoflavonlar dikkati çekmektedir. Bununla birlikte premenapozal ve postmenapozal dönemde olma ile östrojen reseptörünün varlığı (ER+) veya yokluğu (ER-) izoflavonların etkisini değiştirebilmektedir (32). Kore'de yapılan ve izoflavonların koruyucu etkisinin menapoz durumu ve östrojen reseptör varlığı ile ilişkisinin araştırıldığg bir vaka kontrol çalışmasında, koruyucu etki yalnızca postmenapoz dönemdeki ER+ olan kadın bireylerde gözlenmiştir (izoflavon alımı $\geq 23,5 \mathrm{mg} /$ gün) (33). Çin'de yapılan bir vaka-kontrol çalışmasında günlük izoflavon alımı fazla olan kadınlarda ( $>35,1 \mathrm{mg}$ gün) az olanlara $(<12,4 \mathrm{mg} /$ gün$)$ göre meme kanseri riskinin anlamlı olarak daha düşük olduğu bulunmuştur (34). İzoflavonların diyetteki kaynakları soya, soya sütü ve tofu gibi soyadan yapılan besinlerdir. $\mathrm{Bu}$ nedenle izoflavonların özellikle soya ve soya ürünlerini yüksek miktarda tüketen Asya toplumlarında meme kanser riskini önlemede daha etkili olabileceği üzerinde durulmaktadır (35). Amerika'da yapılan kohort çalışma bu sonucu desteklemektedir. Yaklaşık 12,5 yıl boyunca izlenen kadın bireylerde izoflavon alımı ile meme kanseri riski arasında anlamlı bir ilişki bulunmamıştır (36). İspanya' da yürütülen prospektif kohort çalışmada 10.713 yetişkin kadın ortalama 10,3 yıl izlenmiştir. Yapılan değerlendirmede yalnızca postmenapozal kadınlarda toplam polifenol alımı ile meme kanser riski arasında anlamlı negatif ilişki bulunmuştur (37).

Otuz beş çalışmayı içeren bir meta analizde ise izoflavon alımının hem premenapozal hem de post menapozal kadınlarda meme kanser riskini azalttığı gösterilmiştir. Avrupalı kadınlarda ise etkinin sınırlı olduğu vurgulanmaktadır (38). Beslenme kültürü ve östrojen reseptör varlığı izoflavonların meme kanser riskini önlemedeki etkisini değiştirebilmektedir. Ayrıca izoflavonların premenapozda mı yoksa postmenapozda $\mathrm{m}$ daha koruyucu olduğu halen tam olarak belirlenememiştir (32).

Epidemiyolojik çalışmalardan elde edilen veriler bazı polifenollerin kanser riskini azalttığı göstermektedir. Ancak sonuçlarının aşağıda belirtilen nedenlerden dolayı çelişkili ve tartışmalı olduğu düşünülmektedir:

1. Besin tüketimleri değerlendirilirken bazı bitki, baharat ve polifenol içeren suplemanların dikkate alınmaması,

2. Polifenol alımının değerlendirilmesinde kullanılan veri tabanlarının yetersiz olması (bitkilerin polifenol içeriği coğrafik konum, iklim, hasat zamanı, olgunluk 
derecesi, depolama koşulları, işleme yöntemlerinden etkilenmektedir)

3. Toplumların kültürel ve geleneksel alışkanlıklarının farklı olması (örneğin izoflavon alımı Avrupa ülkelerinde $3 \mathrm{mg} /$ gün'den az, Asya ülkelerinde 25-50 mg/gün iken Japonya'da 100 mg/gün'e kadar çıkmaktadır)

4. Bazı fenolik bileşikler kritik zamanlarda kanser riskini azaltmaktadır (örneğin, izoflavonların çocukluk ve adolesan dönemde alımı ileri yaşlarda meme kanser riskini azaltmaktadır)

5. Fenolik bileşiklerin biyoyararlılığının birbirinden farklı olması

6. Antibiyotik kullanımı, stres, alkol tüketimi, diyetle yağ alımının yüksek olması, barsak hastalıkları ve bazı genetik polimorfizmlerin fenolik bileşiklerin biyoyararlılığını azaltması (39).

Polifenol alımının kanser riskini azaltabileceği ancak bu etkinin kanser türü, polifenol türü ve miktarına bağlı olduğu vurgulanmaktadır. Bununla birlikte besin tüketimi ve polifenol alım miktarının kullanılmasının yanıltıcı olabileceği, en doğru yaklaşımın ise polifenollere özgü biyobelirteçlerin kullanılması gerektiği belirtilmektedir (40).

Hücre kültürü ve deney hayvanları çalışmaları, fenolik bileşiklerin kanseri önleme mekanizmalarını moleküler düzeyde incelenmesine olanak sağlamaktadır. Fenolik bileşiklerin farklı kanser hücrelerinde anjiogenez, migrasyon, proliferasyon, metastaz, tümör gelişimini inhibe etmekte, apoptozisi ise indüklediği vurgulanmaktadır. Ancak in vitro ve in vivo çalışmalarda kullanılan fenolik bileşiklerin dozu daha yüksektir Besinlerle bu dozlara erişmek neredeyse imkânsızdır. Bununla birlikte fenolik bileşiklerin biyoyararlılıklarının düşük olması ve yarılanma ömürlerinin kısa olması nedeniyle organizmada beklenen biyolojik aktiviteyi gösteremezler. Örneğin, 50 mg kuarsetin alımıyla plazma kuarsetin düzeyi maksimum 0,75-1,5 $\mu \mathrm{M}$ 'e yükselebilmektedir. $\mathrm{Bu}$ miktar hücre kültürü çalışmalarında kullanılan miktarın 10 katından daha azdır. Ayrıca besinde bulunan diğer besin öğelerinin antogonist veya sinejik etkisi de fenolik bileşiklerin biyolojik aktivitesini etkileyebilmektedir (39). Bu nedenle diyetle alınan fenolik bileşiklerin kanseri önlemede ve tedavi etmedeki rolüne ilişkin kanıtlar sınırlı ve tartışmalıdır.

\subsection{Kanseri Önlemeye ve Tedavi Etmeye Yönelik Klinik Çalışmalar}

\subsubsection{Prostat Kanseri}

Yüksek dereceli prostatik intraepitel neoplazi veya atipik küçük asiner proliferasyon tespit edilen ve protat kanseri gelişme riski olan, 97 erkek bireyde yürütülen randomize kontrollü klinik bir çalışmada deney grubuna 1 yıl boyunca her gün 400 mg epigallo kateşin gallat (EGCG) içeren kapsül verilmiştir (Polyphenol®). EGCG'ın serum prostat spesifik antijen (PSA) düzeyinde azalma sağlamış olsa da kanser gelişme riskini azaltmadığı gösterilmiştir (41).

Yaş ortalaması 74 yıl olan ve prostat kanseri tanısı almış, 199 erkek birey ikiye ayrılarak deney grubu 100 mg nar, $100 \mathrm{mg}$ yeşil çay, $100 \mathrm{mg}$ brokoli ve $100 \mathrm{mg}$ zerdeçal tozu içeren tableti 6 ay boyunca her gün 3 tablet almıştır. Yapılan değerlendirmede plasebo grubunun PSA değeri $\% 14,7$ deney grubunun ise $\% 78,5$ oranında azalmıştır. Nardaki elajik asidin, yeşil çaydaki EGCG'ın, brokolideki sülforafanın ve zerdeçalda bulunan kurkuminin kanser hücrelerinde proliferasyon, invasyon ve metastazı önleyerek ve apoptozisi indükleyerek tedaviye katkı sağladığı bildirilmiştir (42). Yine prostat kanser tansısı almış 90 birey, prostatektomi yapılmadan 3 gruba ayrılarak 1.gruba 6 fincan/gün yeşil çay, 2.gruba 6 fincan/gün siyah çay ve 3.gruba su tükettirilmiştir (1 fincan=240 mL, yeşil ve siyah çay kaynayan suda 5 dakika demlenmiş. Yeşil çayın toplam fenolik içeriği $855,0 \pm 11,8 \mathrm{mg} / \mathrm{L}, \mathrm{EGCG}$ içeriği 396,8 $\pm 28,3 \mathrm{mg} / \mathrm{L}$, siyah çayın toplam fenolik içeriği $661,5 \pm 5,8 \mathrm{mg} / \mathrm{L}$, gallik asit

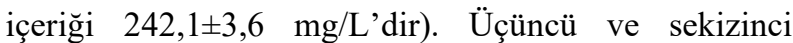
haftaların sonunda yapılan prostatektomi sonrası değerlendirmede yalnızca yeşil çay tüketen grubun prostat dokusunda, çay polifenollerine rastlanmış ve nükleer faktör kappa $\mathrm{B}(\mathrm{NF \kappa B})$ ekpresyonunun azaldığ gözlenmiştir. Ayrıca yalnızca yeşil çay tüketen grupta DNA hasarının bir göstergesi olan üriner 8 hidroksi guanozin (8OHdG) düzeyi ve serum prostat spesifik antijen (PSA) düzeyi anlamlı olarak azalmıştır. Yeşil çayda bulunan EGCG, epikateşin gallat (ECG) ve epigallokateşin (EGC)'nin inflamasyonu ve DNA hasarını korumada etkili olabileceği düşünülmüştür (43). Ancak izoflavonoidlerin prostatektomi yapılmış bireylerdeki etkisini gözlemlemek için yapılan bir çalışmada; deney grubuna 6 hafta boyunca her gün $80 \mathrm{mg}$ izoflavonoid içeren tablet verilmiştir. Yapılan değerlendirmede serum PSA düzeyinde, hücre siklüsunu ve apoptozisi düzenleyen genlerin ekspresyonunda anlamlı bir değişikliğin olmadığı bulunmuştur (44).

\subsubsection{Karaciğer Kanseri}

Tahıllarda bulunan bir mikotoksin türü olan fumonisin karaciğer kanserine yol açabilmektedir. Çin'de misır tüketimi nedeniyle fumonisine maruz kaldığı tespit edilen 124 birey randomize olarak üç gruba ayrılmıştır. Birinci gruba düşük doz (500 mg) yeşil çay polifenolü, ikinci gruba yüksek doz (1000 mg) yeşil çay polifenolü ve üçüncü gruba plasebo verilmiştir. Üçüncü ayın sonunda yapılan değerlendirmede düşük ve yüksek doz yeşil çay polifenolü alan grubun üriner fumonisin düzeyinin sırasıyla $\% 40,2$ ve $\% 52,6$ azaldığı 
bulunmuştur. Yeşil çay polifenollerinin fumonisini bağlayarak üriner atımını kolaylaştırdığı vurgulanmaktadır (45). Metastatik karaciğer kanser tanılı ve hepatektomi yapılması planlanan 9 hastada randomize kontrollü yapılan bir pilot çalışmada, 6 bireye 14 gün boyunca $5 \mathrm{~g}$ mikronize resveratrol verilmiştir. Hepatektomi sonrası karaciğer dokusunda yapılan incelemede, resveratrol alan grupta apoptotik bir belirteç olan kaspaz-3 düzeyinin plasebo grubuna göre \%39 arttı̆̆ gösterilmiştir (46).

Kolorektal kanser tanılı 126 bireyin yer aldığg randomize kontrollü klinik çalışmada, deney grubuna 10 ila 30 gün boyunca günde $3 \mathrm{kez} 360 \mathrm{mg}$ kurkumin içeren kapsül verilmiştir. Çalışma sonunda yapılan değerlendirmede kurkumin alan grubun plazma TNF- $\alpha$ düzeyi, plasebo grubuna göre anlamlı olarak azalırken, vücut ağırlığı anlamlı olarak artmıştır. Ayrıca kolon dokularında yapilan incelemede, apoptozisi uyaran p53 ve Bax ekspresyonunun arttığ ekspresyonunun ise azaldığı gösterilmiştir (47).

\subsubsection{Meme Kanseri}

Amerika'da meme kanseri gelişme riski olan 98 kadın bireyle yürütülen plasebo kontrollü klinik çalışmada; deney grubuna 6 ay boyunca her gün $150 \mathrm{mg}$ genistein, $74 \mathrm{mg}$ daidzein ve $11 \mathrm{mg}$ genistein verilmiștir. Yapılan değerlendirmede deney grubunda bulunan postmenapozal dönemdeki bireylerde epitelyum proliferasyonunun azalmadığı, premenapozal dönemdeki kadınlarda ise izoflavonoidlerin pro-östrojenik etki göstererek epitelyal hücre proliferasyonunu $\% 27$ artırdığ 1 bulunmuştur. İzoflavonoidlerin çocukluktan itibaren soya tüketimi yüksek olan Asya toplumlarında meme kanserine karşı korucu olabileceği vurgulanmıştır (48).

Adjuvan tedavisini bitirmiş evre I-III meme kanser tanılı 40 kadın birey 4 gruba ayrılmıştır. 200 mg EGCG içeren (2-3 fincan demlenmiş yeşil çayın EGCG içeriğine eşit) tabletlerden 1.gruba 2 adet/gün, 2.gruba 3 adet/gün, 3.gruba 4 adet/gün verilmiştir, 4.grup ise plasebo almıştır. EGCG alan grupların serum VEGF düzeyinin 2.ayda $\% 11,5,4$.ayda ise $\% 13,9$ azaldığı gözlemlenmiştir ancak plaseboya göre anlamlı bir fark bulunamamıştır. VEGF düzeyinin azalması anjiogenezin önlenmesi açısından önemlidir ancak EGCG'ın meme kanserli bireylerde kullanılması ile ilgili yapılan çalışma sayısı sinırlıdır (49).

Fenolik bileşiklerin sağlık üzerindeki olumlu etkilerinin yanı sıra bazı yan etkilerine de dikkat çekilmektedir. Olası mekanizmalar aşağıda özetlenmiştir.

1. Normal hücrelerin kanser hücrelerine dönüşümüne neden olarak tümör oluşumunu uyarabilir.

2. Fazla miktarda kullanıldığında sistemik toksisiteyi artırabilir.
3. Enfeksiyonları ve inflamatuvar reaksiyonlara neden olabilir.

4. Antioksidan özelliği olan fenolik asitlerin redoks tepkimelerini katalizleyen metallerin varlı̆̆ında prooksidan etki göstererek DNA hasarına neden olabilir.

Yukarıda belirtilen yan etkilerin görülebilmesi, kullanım dozuna ve süresine bağlıdır. Son araştırmalarda geliştirilen nanoformülasyonların fenolik bileşiklerin yan etkilerini azaltmada etkili olabileceği düşünülmektedir (50).

\section{Sonuç}

Kanserin önlenmesi ve tedavisinde amaç DNA hasarını, angiogenezi, metastazı önlemek ve apoptozisi uyarmaktır. Hücre ve deney hayvanlarında yapılan çalışmalar, fenolik bileşiklerin kanser hücrelerine moleküler düzeyde etkilerinin anlaşılmasını sağlamıştır. İnsanlar üzerinde yapılan klinik çalışmaların sayısı sinırlıdır. Bu nedenle kanserin önlenmesi ve tedavisinde polifenollerin kullanılması ile ilgili görüş birliğinin sağlanması için bilimsel kanttlar yetersizdir. Farklı kanser tür ve evrelerinde kullanılacak olan polifenolün türü, kullanım miktarı ve süresinin belirlenmesi için klinik çalışmalara gereksinim vardır.

Bireyler genetiği, fiziksel ve sosyal çevresi ve alışkanlıklarıyla birlikte bir bütündür. Kanserden korunmak için sağlıklı alışkanlıkların kazanılması (yeterli ve dengeli beslenme, yeterli fiziksel aktivite, sigara ve alkol kullanmama vb.) ve çevresel maruziyetlerin en aza indirilmesi (radyasyon, karsinojenik kimyasal maddeler, pestisitler vb. ) önerilmektedir. Ayrıca bireyler polifenol içeriği yüksek olan sebze ve meyveleri her gün yeterli miktarda ve uygun hazırlama-pişirme yöntemleri kullanarak tüketmesi konusunda bilinçlendirilmelidir.

\section{Referanslar}

1. The International Agency for Research on Cancer, Cancer Today. ,https://gco.iarc.fr/today/online-analysis-

pie $? \mathrm{v}=2018 \&$ mode $=$ cancer\&mode_population $=$ continents $\&$ populati on $=900 \&$ populations $=900 \&$ key $=$ total $\&$ sex $=0 \&$ cancer $=39 \&$ type $=0$ $\&$ statistic $=5 \&$ prevalence $=0 \&$ population_group=0\&ages_group $\% 5 \mathrm{~B}$ $\% 5 \mathrm{D}=0 \&$ ages_group\%5B\%5D=17\&nb_items=7\&group, $\quad 2019$ (Erişim Tarihi:23.12.2019)

2. Fymat, AL, Genetics, epigenetics and cancer, Cancer Therapy and Oncology, 2014, 1-3.

3. Grant, B, Hamilton, K, Medical nutrition therapy for cancer prevention, treatment, and recovery. In: Process Mahan L, Raymond J, Escott-Stum (ed) Krause's food \& the nutrition care, 13th edm. Elsevier/Saunder, St. Louis, 2012.

4.Lewandowska, A, Rudzki, M, Rudzki, S, Lewandowski, T, Laskowska, B, Environmental risk factors for cancer - review paper, Annals of Agricultural and Environmental Medicine, 2019, 26(1), 17.

5. Sausville, E.A, Longo, D.L, Principles of Cancer Treatment. In: Kasper D, Fauci A, Hauser S, Longo D, Jameson J.L, Loscalzo J (ed) Harrison's Principles of Internal Medicine, 17th. edn. McGraw-Hill 
Professional.New York, United States, 2008.

6. Kawabata, K, Yoshioka, Y, Terao, J, Role of intestinal microbiota in the bioavailability and physiological functions of dietary polyphenols, Molecules, 2019, 24(2), 370.

7. Spencer, J.P.E, Abd El Mohsen, M.M, Minihane, A.M, Mathers, J.C Biomarkers of the intake of dietary polyphenols: strengths, limitations and application in nutrition research, British Journal of Nutrition, 2008, 99(1), 12-22.

8. Grosso, G, Stepaniak, U, Topor-Mądry, R, Szafraniec, K, Pająk, A, Estimated dietary intake and major food sources of polyphenols in the Polish arm of the HAPIEE study, Nutrition, 2014, 30(11-12), 1398-403.

9. Miranda, A.M, Steluti, J, Fisberg, R.M, Marchioni, D.M, Dietary intake and food contributors of polyphenols in adults and elderly adults of Sao Paulo: a population-based study, British Journal of Nutrition, 2016, 115(6), 1061-70.

10. Zamora-Ros, R, Knaze, V, Rothwell, J.A, Hémon, B, Moskal, A, Overvad, K, et al., Dietary polyphenol intake in Europe: the European Prospective Investigation into Cancer and Nutrition (EPIC) study, European Journal of Nutrition, 2016, 55(4), 1359-75.

11. Godos, J, Marventano, S, Mistretta, A, Galvano, F, Grosso, G, Dietary sources of polyphenols in the Mediterranean healthy Eating, Aging and Lifestyle (MEAL) study cohort, International Journal of Food Sciences and Nutrition, 2017, 68(6), 750-6.

12. Amawi, H, Ashby, C, Samuel, T, Peraman, R, Tiwari, A, Polyphenolic nutrients in cancer chemoprevention and metastasis: Role of the epithelial-to-mesenchymal (EMT) pathway, Nutrients 2017, 9(8), 911.

13. Hussain, S.A, Sulaiman, A.A, Balch, C, Chauhan, H, Alhadidi, Q.M, Tiwari, A.K, Natural polyphenols in cancer chemoresistance, Nutrition and Cancer, 2016, 68(6), 879-91.

14. Christensen, K.Y, Naidu, A, Parent, M-É, Pintos, J, Abrahamowicz, M, Siemiatycki, J, et al., The risk of lung cancer related to dietary intake of flavonoids, Nutrition and Cancer, 2012, 64(7), 964-74.

15. Guo, Z, Jiang, M, Luo, W, Zheng, P, Huang, H, Sun, B., Association of lung cancer and tea-drinking habits of different subgroup populations: Meta-analysis of case-control studies and cohort studies, Iranian Journal of Public Health, 2019, 48(9), 1566-76.

16. Russo, G, Campisi, D, Di Mauro, M, Regis, F, Reale, G, Marranzano, M, et al., Dietary consumption of phenolic acids and prostate cancer: A case-control study in Sicily, Southern Italy, Molecules, 2017, 22(12), 2159

17. Wang, Y, Stevens, V.L, Shah, R, Peterson, J.J, Dwyer, J.T, Gapstur S.M, et al., Dietary flavonoid and proanthocyanidin intakes and prostate cancer risk in a prospective cohort of US Men. American Journal of Epidemiology, 2014, 179(8), 974-86.

18. Guo, K, Liang, Z, Liu, L, Li, F, Wang, H, Flavonoids intake and risk of prostate cancer: a meta-analysis of observational studies, Andrologia, 2016,48(10),1175-82.

19. Guo, Y, Zhi, F, Chen, P, Zhao, K, Xiang, H, Mao, Q, et al., Green tea and the risk of prostate cancer, Medicine, 2017, 96(13), e6426.

20. Xu, M, Chen, Y-M, Huang, J, Fang, Y-J, Huang, W-Q, Yan, B, et al., Flavonoid intake from vegetables and fruits is inversely associated with colorectal cancer risk: a case-control study in China, British Journal of Nutrition, 2016, 116(7), 1275-87.

21. Nimptsch, K, Zhang, X, Cassidy, A, Song, M, O’Reilly, É.J, Lin, J.H, et al., Habitual intake of flavonoid subclasses and risk of colorectal cancer in 2 large prospective cohorts, The American Journal of Clinical Nutrition, 2016, 103(1), 184-91.

22. Grosso, G, Godos, J, Lamuela-Raventos, R, Ray, S, Micek, A, Pajak, A, et al.,. A comprehensive meta-analysis on dietary flavonoid and lignan intake and cancer risk: Level of evidence and limitations, Molecular Nutrition \& Food Research, 2017, 61(4), 1600930.

23. He, X, Sun, L, Dietary intake of flavonoid subclasses and risk of colorectal cancer: evidence from population studies. Oncotarget 2016, 7(18), 26617-27.
24. Chen, Y, Wu, Y, Du, M, Chu, H, Zhu, L, Tong, N, et al. An inverse association between tea consumption and colorectal cancer risk. Oncotarget, 2017, 8(23), 37367-76.

25. Zamora-Ros, R, Agudo, A, Lujan-Barroso, L, Romieu, I, Ferrari, P Knaze, V, et al. Dietary flavonoid and lignan intake and gastric adenocarcinoma risk in the European Prospective Investigation into Cancer and Nutrition (EPIC) study, The American Journal of Clinical Nutrition, 2012, 96(6), 1398-408

26. Woo, H.D, Lee, J, Choi, I.J, Kim, C.G, Lee, J.Y, Kwon, O, et al., Dietary flavonoids and gastric cancer risk in a Korean population, Nutrients, 2014, 6(11), 4961-73.

27. Xie, Y, Huang, S, Su, Y, Dietary flavonols intake and risk of esophageal and gastric cancer: A meta-analysis of epidemiological studies, Nutrients, 2016, 8(2).

28. Golpour, A, Rafie, N, Safavi, S.M, Miraghajani, M, Dietary isoflavones and gastric cancer: A brief review of current studies, Journal of Research in Medical Sciences, 2015, 893-900.

29. Lagiou, P, Rossi, M, Lagiou, A, Tzonou, A, La Vecchia, C, Trichopoulos, D. Flavonoid intake and liver cancer: A case-control study in Greece, Cancer Causes Control, 2008, 19(8), 813-8.

30. Zamora-Ros, R, Fedirko, V, Trichopoulou, A, González, C.A, Bamia, C, Trepo, E, et al., Dietary flavonoid, lignan and antioxidant capacity and risk of hepatocellular carcinoma in the European prospective investigation into cancer and nutrition study, International Journal of Cancer, 2013, 133(10), 2429-43.

31. Kurahashi, N, Inoue, M, Iwasaki, M, Tanaka, Y, Mizokami, M, Tsugane, S, Isoflavone consumption and subsequent risk of hepatocellular carcinoma in a population-based prospective cohort of Japanese men and women, International Journal of Cancer, 2009, 124(7), 1644-9.

32. Sak, K. Epidemiological evidences on dietary flavonoids and breast cancer risk: A narrative review, Asian Pacific Journal of Cancer Prevention, 2017, 2309-28.

33. Cho, Y.A, Kim, J, Park, K.S, Lim, S.Y, Shin, A, Sung, M.K, et al., Effect of dietary soy intake on breast cancer risk according to menopause and hormone receptor status, European Journal of Nutrition, 2010, 64(9), 924-32.

34. Li, L, Zhang, M, Holman, CDJ, Population versus hospital controls in the assessment of dietary intake of isoflavone for case-control studies on cancers in China, Nutrition and Cancer, 2013, 65(3), 3907

35. Maskarinec, G, Ju, D, Morimoto, Y, Franke, A.A, Stanczyk, F.Z, Soy food intake and biomarkers of breast cancer risk: Possible difference in Asian women? Nutrition and Cancer, 2017, 69(1), 146-53.

36. Morimoto, Y, Maskarinec, G, Park, S.Y, Ettienne, R, Matsuno, R.K, Long, C, et al., Dietary isoflavone intake is not statistically significantly associated with breast cancer risk in the Multiethnic Cohort, British Journal of Nutrition, 2014, 112(6), 976-83

37. Gardeazabal, I, Romanos-Nanclares, A, Martínez-González, M.Á, Sánchez-Bayona, R, Vitelli-Storelli, F, Gaforio, J.J, et al., Total polyphenol intake and breast cancer risk in the Seguimiento Universidad de Navarra (SUN) cohort, British Journal of Nutrition, 2019, 122(05), 542-51

38. Chen M, Rao Y, Zheng Y, Wei S, Li Y, Guo T, ve ark. Association between soy isoflavone intake and breast cancer risk for pre- and post-menopausal women: A meta-analysis of epidemiological studies, PLoS One, 2014, 9(2).

39. Sak, K. Intake of individual flavonoids and risk of carcinogenesis overview of epidemiological evidence, Nutrition and Cancer, 2017 $, 69,1119-50$

40. Rothwell, J.A, Knaze, V, Zamora-Ros, R, Polyphenols: Dietary assessment and role in the prevention of cancers, Current Opinion in Clinical Nutrition \& Metabolic Care, 2017, 512-21.

41. Kumar, N.B, Pow-Sang, J, Egan, K.M, Spiess, P.E, Dickinson, S, Salup, R, et. al., Randomized, placebo-controlled trial of green tea catechins for prostate cancer prevention, Cancer Prevention 
Research, 2015, 8(10), 879-87.

42. Thomas, R, Williams, M, Sharma, H, Chaudry, A, Bellamy, P, A double-blind, placebo-controlled randomised trial evaluating the effect of a polyphenol-rich whole food supplement on PSA progression in men with prostate cancer - The UK NCRN Pomi-T study, Prostate Cancer and Prostatic Diseases, 2014, 17(2), 180-6.

43. Henning, S.M, Wang, P, Said, J.W, Huang, M, Grogan, T, Elashoff, $\mathrm{D}$, et al., Randomized clinical trial of brewed green and black tea in men with prostate cancer prior to prostatectomy, Prostate, 2015 , 75(5), 550-9.

44. Hamilton-Reeves, J.M, Banerjee, S, Banerjee, S.K, Holzbeierlein, J.M, Thrasher, J.B, Kambhampati, S, et al., Short-Term soy 1soflavone intervention in patients with localized prostate cancer: A randomized, double-blind, placebo-controlled trial, PLoS One, 2013 , $8(7)$.

45. Xue, KS, Tang, L, Cai, Q, Shen, Y, Su, J, Wang, JS, Mitigation of fumonisin biomarkers by green tea polyphenols in a high-risk population of hepatocellular carcinoma, Scientific Reports, 2015, 5.

46. Howells, LM, Berry, DP, Elliott, PJ, Jacobson, EW, Hoffmann, E, Hegarty, B, et al., Phase I randomized, double-blind pilot study of micronized resveratrol (SRT501) in patients with hepatic metastases - safety, pharmacokinetics, and pharmacodynamics, Cancer Prevention Research, 2011, 4(9), 1419-25.

47. He, Z.Y, Shi, C.B, Wen, H, Li, F.L, Wang, B.L, Wang, J, Upregulation of p53 expression in patients with colorectal cancer by administration of curcumin, Cancer Investigation, 2011, 29(3), 20813.

48. Khan, S.A, Chatterton, R.T, Michel, N, Bryk, M, Lee, O, Ivancic, D, et al., Soy isoflavone supplementation for breast cancer risk reduction: A randomized phase II trial, Cancer Prevention Research 2012, 5(2), 309-19.

49. Crew, K.D, Ho, K.A, Brown, P, Greenlee, H, Bevers, T.B, Arun, B, et al., Effects of a green tea extract, Polyphenon E, on systemic biomarkers of growth factor signalling in women with hormone receptor-negative breast cancer, Journal of Human Nutrition and Dietetics, 2015, 28(3), 272-82.

50. Anantharaju, P.G, Gowda, P.C, Vimalambike, M.G, Madhunapantula, S.V, An overview on the role of dietary phenolics for the treatment of cancers, Nutrition Journal, 2016, 15(1), 99.

http://edergi.cbu.edu.tr/ojs/index.php/cbusbed isimli yazarın CBU-SBED başlıklı eseri bu Creative Commons Alınt1-Gayriticari4.0 Uluslararası Lisansı ile lisanslanmıştır.

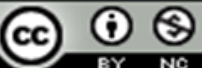

